\title{
Assessment of Infectious Waste Management Practices at Hospital with Excellent Accreditation Level in Bandung, Cimahi and East Jakarta, Indonesia
}

\author{
Novi Fitria ${ }^{1,2, *}$, Enri Damanhuri ${ }^{1}$, and Indah R.S Salami ${ }^{1}$ \\ ${ }^{1}$ Faculty of Civil and Environment Engineering, Bandung Institute of Technology, Jl. Ganesha 10, Bandung 40132, Indonesia \\ ${ }^{2}$ Bakti Asih Higher education School of Analyst Bakti Asih Bandung, Jl. Padasuka Atas 233, Bandung 40192, Indonesia
}

\begin{abstract}
This study includes the procedures available and methods of handling and disposing of infectious waste at Military hospital with Excellent Accreditation level in Bandung, Cimahi and East Jakarta, Indonesia. A total three (3) military hospitals with equal type of hospital and level accreditation were surveyed during the course of this research. The methods consisted of survey and interview with the authorities of the hospital and the personal involved in the management of the generated waste. The information was collected using forms specially developed for this purpose. Site visits were conducted to support and supplement information gathered in the survey. Assessment of infectious waste handling divided into six parameters: Hospital policy at organizational structure, status of cleaning services worker, classification/segregation process, collect and transport the infectious waste, condition of temporary storage of infectious waste and disposal phase of infectious waste. The result showed that the hospital with highest level of accreditation have less appropriate practices when it comes to segregation, collecting, storage and disposal of waste generated in comparison to developed country. It appears that hospital authorities should pay better attention to educational planning, organizational resources and supervision at infectious waste management.
\end{abstract}

\section{Introduction}

Infectious waste from hospital has proven ability to transmit disease among healthcare workers and other individuals. Oroei [1] studied that infectious waste accounts for approximately $15-25 \%$ of all medical waste; however it has the potential to negatively affect human safety and health. A definition of infectious based on Stankovic [2], US EPA [3], Komilis [4], Nwachukwu [5] and government regulation PP 101/2014 [6] separate different types of waste.

Infectious waste includes anything potentially infectious, such as body fluids or secretion (e.g., blood, pleural fluid, semen, vaginal secretion, vomit, feces or urine), contaminated sharp object (e.g., contaminated needles, syringe and surgical blades), biological laboratory waste (e.g., cultures, stocks and growth media), pathological waste (e.g., human tissue, organs or body fluids), and single use disposable equipment, utensils and instrument soiled with potentially infectious agents. Hospital's facility or area that become source of infectious waste (e.g., isolation wards, emergency room (IGD), operating theatres, intensive care units (ICU), pathological and biological laboratories (Clinic pathology)

The World Health Organization (WHO) [7] has advocated that hospital waste should be treated as special wastes from Bdour [8] research. because it's volume and the complexity of hospital infectious waste increase, the risk of transmitting disease through unsafe handling and disposal practices also increases. The rise in incidence of such disease as AIDS, hepatitis $\mathrm{B}$ and $\mathrm{C}$ makes the possibility of infection of personal handling these waste and risk to public health arising from the transport of infectious waste. Hospitals are the biggest source of infectious waste.

Based on Fitria [9] studied that in one governance hospital in Bandung, in past two years (2015 and 2016) The Increased of medical waste generation varies greatly with range $35-556 \%$. Infectious waste extremely increased in body tissue, syringe and intravenous bag category $(556 \%, 533 \%$ and $444 \%)$. The Infectious waste now growing globally to impose stricter controls on handling and disposal of waste generated by hospital. This is an extension of the common concern for hospital to improve a monitoring and evaluating on infectious waste management should be an integral part of hospital management.

In Indonesia, to achieved a better practice in services to patients but still keep the integrity to environment concern, in 2012 based on regulation of the ministry of health (Permenkes no 12 /2012) [10], hospital must have accreditation level. The purpose from hospital accreditation program is to increase quality assurance to patients and environment. Hospital accreditations have three (3) level of assessment. Level one (1) includes 5 steps of assessment, level two (2) includes 12 steps of assessment and level three (3) of accreditation 
assessment includes 16 steps. The highest level of hospital accreditation assessment is level 3 with 16 steps of assessment excellent level. This condition describe the hospital with highest level of accreditation already settle the obligation to implement the appropriate rules and procedures in hospital management include the rules and procedures of infectious waste handling and disposal.

However in developing country such as Indonesia, the management hospital was in consist to implement the commitment, especially in infectious disease control. Sometimes budget issue is the reason for misconduct of infectious waste handling and disposal. Patwari [11] has studied, in many countries hazardous and medical waste are still handled and disposed of together with domestic, thus creating a health risk to healthcare worker, the public and environment.

Very few studies have been conducted on infectious waste in Indonesia that related to relationship between hospital accreditation level with its implementation especially on the handling and disposal of infectious hospital waste management. Furthermore, most our knowledge of hospital infectious waste management is limited. Thus, research required to establish database and information on hospital infectious waste handling and disposal. The objective of this study are directed towards: (1) conducting a survey of available procedures, techniques and methods of handling and disposal of hospital infectious waste that related to hospital accreditation level; and (2) Identifying the important characteristics and their possible influence of misconduct the handling and disposal implementation on hospital infectious waste.

\section{Materials and Methods}

This study was conducted at three (3) hospitals that have same class, type and level of hospital accreditation. The three hospitals were coded to maintain data confidentiality. The characteristic of the hospitals are military hospital with type of hospital "B" and excellent level accreditation. Hospital that located in Bandung, Cimahi and East Jakarta, Indonesia were coded with hospital "A", "B" and "C". Hospital facilities in this study assumed practice a good management of infectious waste and concern to environmental issue. Furthermore we have to explore how far the level of accreditation could make any progress in infectious waste management. Data collection lasted for three months January until March, 2017 after receiving approval from Ethics Research Community of Dustira Hospital, Cimahi. The methods consisted of survey and interview with the authorities of the hospital and the personal involved in the management of the generated waste. The information was collected using forms specially developed for this purpose. Site visits were conducted to support and supplement information gathered in the survey. Interviews and site visits were helpful in obtaining information about common practices in the management of the infectious waste (e.g., handling, segregation, transport, storage, treatment, and final disposal). Qualitative analysis used as research methods.
Table 1 shows the hospital code, types and other information about study area.

Table.1. Summary of studied hospital

\begin{tabular}{|c|c|c|c|c|}
\hline $\begin{array}{c}\text { Hospital } \\
\text { Code }\end{array}$ & Owner & Class & $\begin{array}{c}\text { Accreditation } \\
\text { level }\end{array}$ & $\begin{array}{c}\text { Number } \\
\text { of Beds }\end{array}$ \\
\hline A & $\begin{array}{c}\text { Military- } \\
\text { Governmental } \\
\text { Bandung }\end{array}$ & B & Excellent & 192 \\
\hline B & $\begin{array}{c}\text { Military- } \\
\text { Governmental } \\
\text { Cimahi }\end{array}$ & B & Excellent & 496 \\
\hline C & $\begin{array}{c}\text { Military- } \\
\text { Governmental } \\
\text { East Jakarta }\end{array}$ & B & Excellent & 138 \\
\hline
\end{tabular}

\section{Results and Discussion}

\subsection{Organizaional Structure}

Organizational structure is an arrangement or relationship between components if various parts and positions within an organization, the components contained in an organization have a dependency. So if there is a good component it will affect the other components and of course will affect the organization. In hospital $\mathrm{A}$ and $\mathrm{C}$, the handling of infectious waste carried out under the supervision of environmental health department and evaluated by control of infectious diseases department (CID's) as showed at Fig. 1. But the opposite, in hospital B, infectious waste handling and control infectious diseases under in same authority which is health and safety department as showed at Fig. 2.

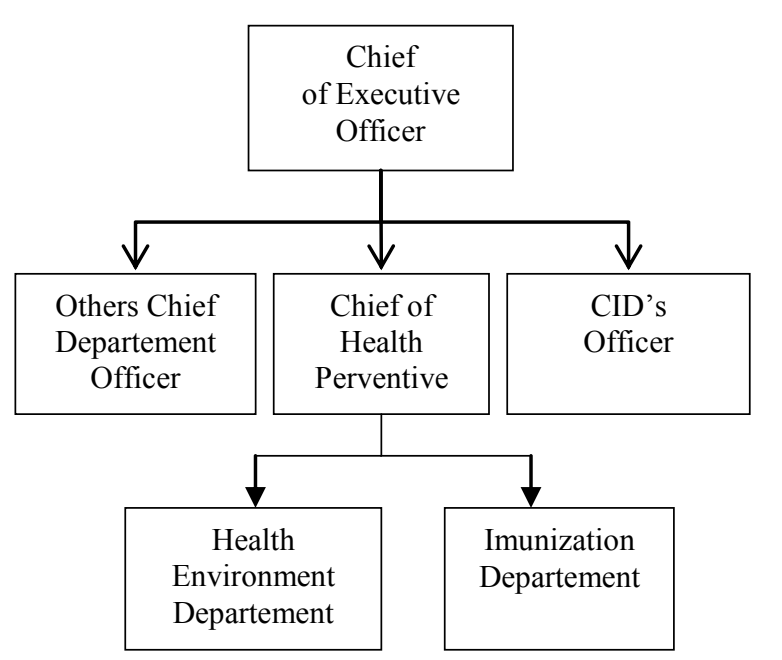

Fig.1. Organizational structure and infectious waste at Hospital $\mathrm{A}$ and $\mathrm{C}$.

\footnotetext{
Corresponding author: novie.fitria@gmail.com
} 


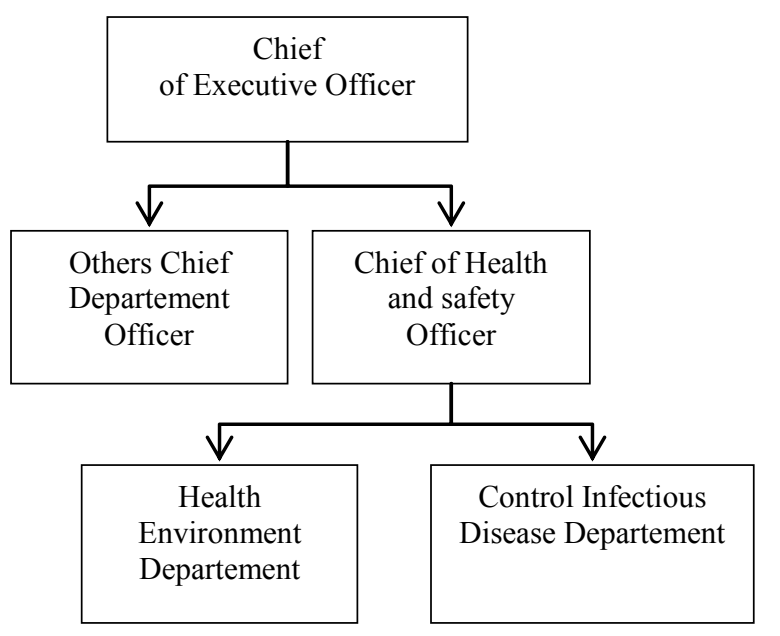

Fig.2. Organizational structure and infectious waste at Hospital B.

\subsection{Hospital Cleaning Service Status}

Hospital cleaning service personnel have the main duty to always maintain the cleanliness of the hospital. One of their tasks is to transport infectious waste from outpatient and inpatient facilities. Transportation of infectious waste is scheduled twice a day. In the morning, transport of infectious waste scheduled at 7 o'clock am and on the afternoon, transport is scheduled at 5 o'clock pm. The status of cleaning service personnel in the hospital varies. Hospital $\mathrm{A}$ and $\mathrm{C}$ have their cleaning service personnel status is as contract labor officer.

The management of worker status of the cleaning service personnel is still under the authority of the hospital's human resources department. The opposite, in hospital B the status of hospital cleaning service personnel uses outsourcing services, their status not under the authority of the hospital's human resources department. Differences in hospital cleaning service personnel status can have an impact on the implementation of infectious hospital waste management.

\subsection{Segregation, Transport, Storage and Disposal of Hospital Infectious Waste}

In general, the separation of infectious waste in the three hospitals has the same procedure. The three hospitals simply divide infectious waste into two categories, infectious and non-infectious waste. In infectious waste there is no further separation, although it has a different container between sharp and non-sharp infectious wastes, eventually disposing of both are placed in the same container that is in a yellow plastic bag. While non-infectious waste placed on a black plastic bag.

Based on International regulation, Kumari [12] studied there are six (6) segregation of hospital infectious waste (Table 2). In this study the category of infectious waste color coding divided into yellow and black plastic bag (Table 3 ).
Table.2. Different categories of waste along with international regulation color coding.

\begin{tabular}{|c|c|c|}
\hline Category & Items & $\begin{array}{c}\text { Color } \\
\text { Coding } \\
\end{array}$ \\
\hline $\begin{array}{l}\text { General } \\
\text { waste }\end{array}$ & $\begin{array}{l}\text { Paper, wrappers, peels of fruit } \\
\text { and vegetables, remains of food } \\
\& \text { edibles etc. }\end{array}$ & Black \\
\hline \multicolumn{3}{|c|}{ Bio - Medical waste } \\
\hline $\begin{array}{l}\text { Non-plastic } \\
\text { infectious } \\
\text { waste }\end{array}$ & $\begin{array}{c}\text { Human and animal anatomical } \\
\text { waste, waste contaminated with } \\
\text { blood, and body fluids including } \\
\text { cotton, dressings, soiled plaster } \\
\text { casts, lines beddings, other } \\
\text { material contaminated with } \\
\text { blood. }\end{array}$ & Yellow \\
\hline $\begin{array}{l}\text { Plastics } \\
\text { infectious } \\
\text { waste }\end{array}$ & $\begin{array}{l}\text { Disposable items such as } \\
\text { glucose bottle, hub remove } \\
\text { syringe tube, catheters, } \\
\text { intravenous sets, gloves etc. }\end{array}$ & Red \\
\hline Sharp waste & $\begin{array}{l}\text { Needles, scalpels, blade, etc. } \\
\text { that may cause puncture and } \\
\text { cuts, this includes both used and } \\
\text { unused sharp etc. }\end{array}$ & $\begin{array}{l}\text { Puncture } \\
\text { proof red } \\
\text { container }\end{array}$ \\
\hline Glass waste & $\begin{array}{l}\text { Glass materials like bottle, } \\
\text { ampoules, slide, tubes, etc. }\end{array}$ & White \\
\hline Liquid waste & $\begin{array}{l}\text { Waste generated from laboratory } \\
\text { and washing, cleaning, } \\
\text { housekeeping and disinfecting } \\
\text { activities, Chemical used in } \\
\text { production of biological, } \\
\text { chemicals used in disinfection, } \\
\text { as insecticides etc. }\end{array}$ & Blue \\
\hline
\end{tabular}

Based on the results of interviews shows that the hospital management difficulty getting a supplier of red and purple plastic bags. In addition, the price of purple and red plastic bags is more expensive than the black or yellow plastic bags. The higher price of plastic bag in other color becomes the influencing factor. Sometimes it doesn't fit with the purchase budget.

The practice of separation of infectious and noninfectious waste hospital generally has the same problem, which infectious waste and non-infectious waste has been mixed starting from the source. This is due to the depletion of yellow plastic stock as a hospital infectious waste container. The delays caused the nurse used the black plastic bag to collect the infectious waste.

Hospitals that do not use outsourcing services in their hygiene worker status (hospitals $\mathrm{A}$ and $\mathrm{C}$ ), have run out of plastic bags a few times due to hospital purchase delays. But hospital B that used outsourcing services, almost never run out of yellow plastic bags. Because based on on-going contracts with outsourcers, all infectious and non-infectious containers have been provided automatically. In this case prove that using outsourcing services due to infectious waste handling more safe and effective.

\footnotetext{
Corresponding author: novie.fitria@gmail.com
} 
Table. 3. Segregation practice based on color coding at Hospital A,B and C.

\begin{tabular}{|c|c|c|}
\hline Category & Items & $\begin{array}{l}\text { Color } \\
\text { Coding }\end{array}$ \\
\hline $\begin{array}{l}\text { General } \\
\text { waste }\end{array}$ & $\begin{array}{l}\text { Paper, wrappers, peels of } \\
\text { fruit and vegetables, } \\
\text { remains of food \& edibles } \\
\text { etc. }\end{array}$ & Black \\
\hline \multicolumn{3}{|c|}{ Bio - Medical waste } \\
\hline $\begin{array}{l}\text { Non-plastic } \\
\text { infectious } \\
\text { waste }\end{array}$ & $\begin{array}{c}\text { Human and animal } \\
\text { anatomical waste, waste } \\
\text { contaminated with blood, } \\
\text { and body fluids including } \\
\text { cotton, dressings, soiled } \\
\text { plaster casts, lines } \\
\text { beddings, other material } \\
\text { contaminated with blood. }\end{array}$ & Yellow \\
\hline $\begin{array}{l}\text { Plastics } \\
\text { infectious } \\
\text { waste }\end{array}$ & $\begin{array}{l}\text { Disposable items such as } \\
\text { glucose bottle, hub } \\
\text { remove syringe tube, } \\
\text { catheters, intravenous } \\
\text { sets, gloves etc. }\end{array}$ & Yellow \\
\hline Sharp waste & $\begin{array}{l}\text { Needles, scalpels, blade, } \\
\text { etc., that may cause } \\
\text { puncture and cuts, this } \\
\text { includes both used and } \\
\text { unused sharp etc. }\end{array}$ & $\begin{array}{l}\text { Puncture } \\
\text { proof } \\
\text { Yellow } \\
\text { container }\end{array}$ \\
\hline Glass waste & $\begin{array}{c}\text { Glass materials like } \\
\text { bottle, ampoules, slide, } \\
\text { tubes, etc. }\end{array}$ & Yellow \\
\hline $\begin{array}{l}\text { Liquid } \\
\text { waste }\end{array}$ & $\begin{array}{l}\text { Waste generated from } \\
\text { laboratory and washing, } \\
\text { cleaning, housekeeping } \\
\text { and disinfecting activities, } \\
\text { Chemical used in } \\
\text { production of biological, } \\
\text { chemicals used in } \\
\text { disinfection, as } \\
\text { insecticides etc. }\end{array}$ & $\begin{array}{l}\text { White and } \\
\text { yellow } \\
\text { plastic } \\
\text { container }\end{array}$ \\
\hline
\end{tabular}

However the hospital management should start to concern about quality of yellow and black plastic bag. Every year the price of plastic bags is increasing and it is not accompanied with the budget to purchase the plastic bags, it makes the hospital management selected the lower quality of plastic bags. The impact of this decision, yellow plastic bags easily tear and spill out the content.

At transportation phase, the transport of infectious and non-infectious waste from the treatment room to the waste bin is temporarily practiced in different ways although the procedure for transporting infectious waste is already referring to the correct standards based on Chen [13]. Fig. 3 shows the standard procedure for transporting infectious waste. In the procedure there is a phase that infectious waste should through the sterilization process before weighing process done.

Fig. 4 shows that in hospital A have mismanagement of the transport of infectious and non-infectious waste from treatment room to temporary storage is practiced on the same garbage trolley. Yellow and black plastic bags were brought in the same trolley to temporary storage.

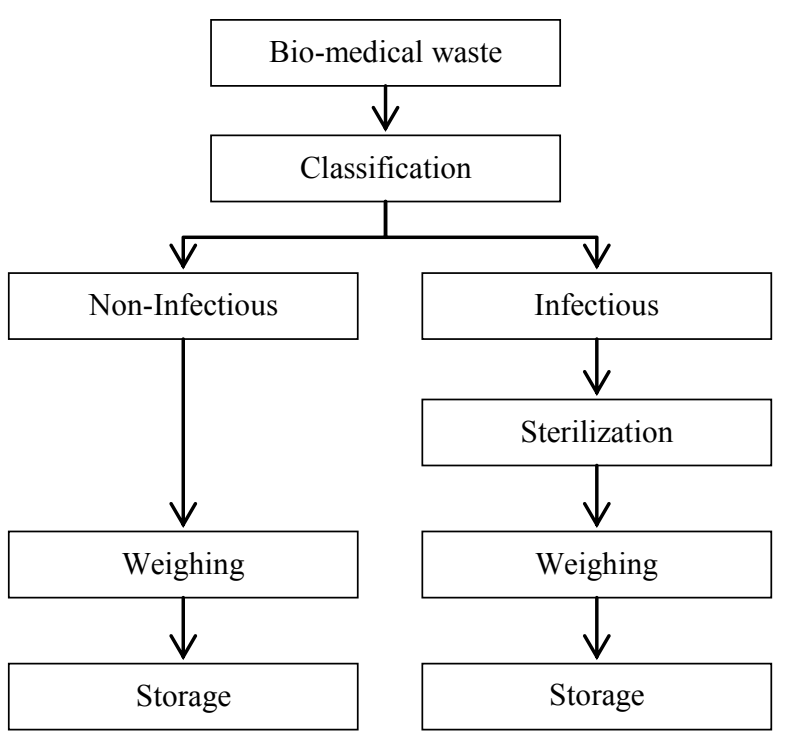

Fig.3. Standard treatment processes for infectious waste and noninfectious waste

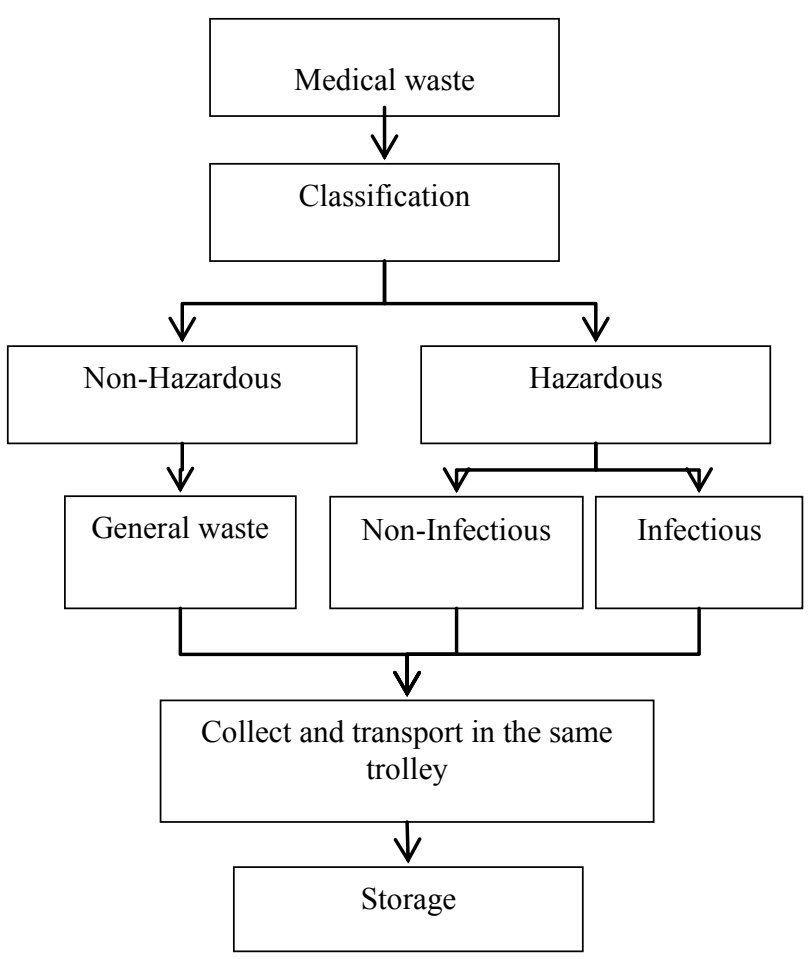

Fig.4. Treatment processes for infectious waste and noninfectious waste at Hospital A

Hospital B using outsourcing services to transport infectious and non-infectious waste, both are transported by different trolleys. Fig.5 shows the path of infectious waste handling in real activities at hospital B. After the infectious waste arrived at temporary waste, the cleaning services sorting between plastic and non-plastic infectious waste to reduce the volume of infectious waste, after that, the non-plastic infectious waste will be incinerated. At hospital $\mathrm{C}$, the transport of infectious and

\footnotetext{
Corresponding author: novie.fitria@gmail.com
} 
non-infectious waste practiced separately, but before the infectious waste placed in infectious temporary storage area, infectious waste is transported to a place where non-infectious waste is located. This happens because there is a practice of sorting on infectious waste before being placed in temporary storage.

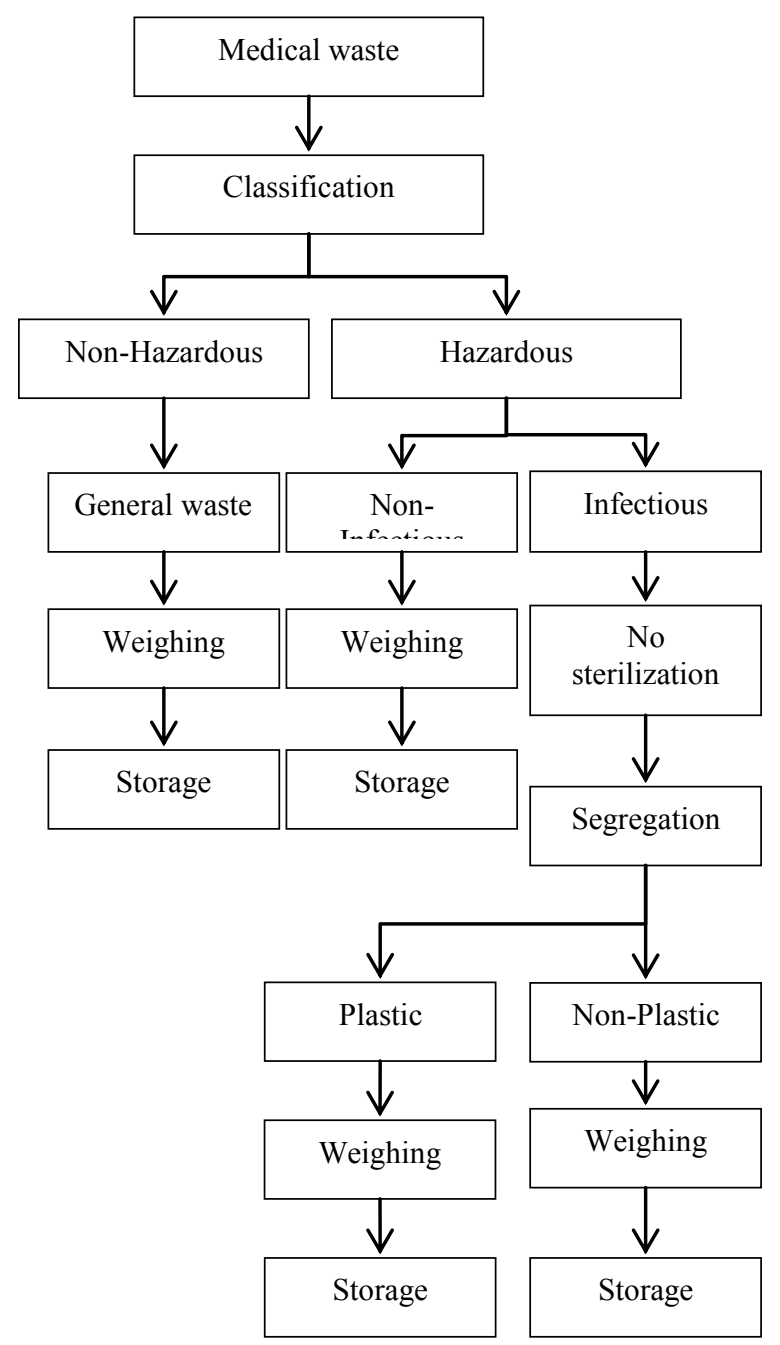

Fig.5. Treatment processes for infectious waste and non infectious waste at Hospital B

Based on the regulation of infectious waste transportation, the infectious waste must through the sterilization process before weighing and storage phase. However none the hospitals practiced the sterilization process, because the price of sterilization equipment for infectious waste is very expensive. Disadvantages of infectious waste transport practices at hospital $\mathrm{C}$ as illustrated in Fig.6 shows that the cleaning services workers carrying infectious and non-infectious waste at the same time. Procedurally, infectious waste carried separately with non-infectious waste. The impact of this infectious waste transport practice will lead to general waste and non-infectious waste being automatically became infectious waste. At the end the general waste and non-infectious waste that already change the status became infectious waste will be transport from temporary storage to open dumping landfill area.
If the nurse cannot find yellow plastic bag for infectious waste, they will use black plastic bag to collect the infectious waste from treatment room. Cleaning services worker will not recheck what inside of black plastic bag. They will be direct put the black plastic bag that contain infectious waste in general waste temporary storage. Infectious waste will arrived along the municipal waste to open dumping area.The reason they conduct this practices because the temporary storage of infectious waste and non-infectious waste are in same location and there is no warning from their supervisor. Interview result with cleaning services worker show, that actually they know and notice about the infectious wate standard procedures, but they ignore the procedures with efficiency and effectiveness times reason and they can finish their job faster.

Infectious waste transport practices in hospital B as illustrated in Figure 9 show that the cleaning services worker conduct the infectious waste trasport as the standard procedures. But there is activity that the cleaning services worker sorted infectious waste in temporary storage 3 . The cleaning services worker seperated between plastic infectious and non-plastic infectious waste before disposal process done. This activity will risk the cleaning services worker health exposure by infectious diseases. They conduct the seperation activity because instruction from the hospital management in purpose to reduce over budget for infectious waste disposal. Hospital B has an incinerator which can use to incinerated non-plastic infectious waste. At the end the hospital will only pay to third party to dispose their infectious waste in plastic category only.

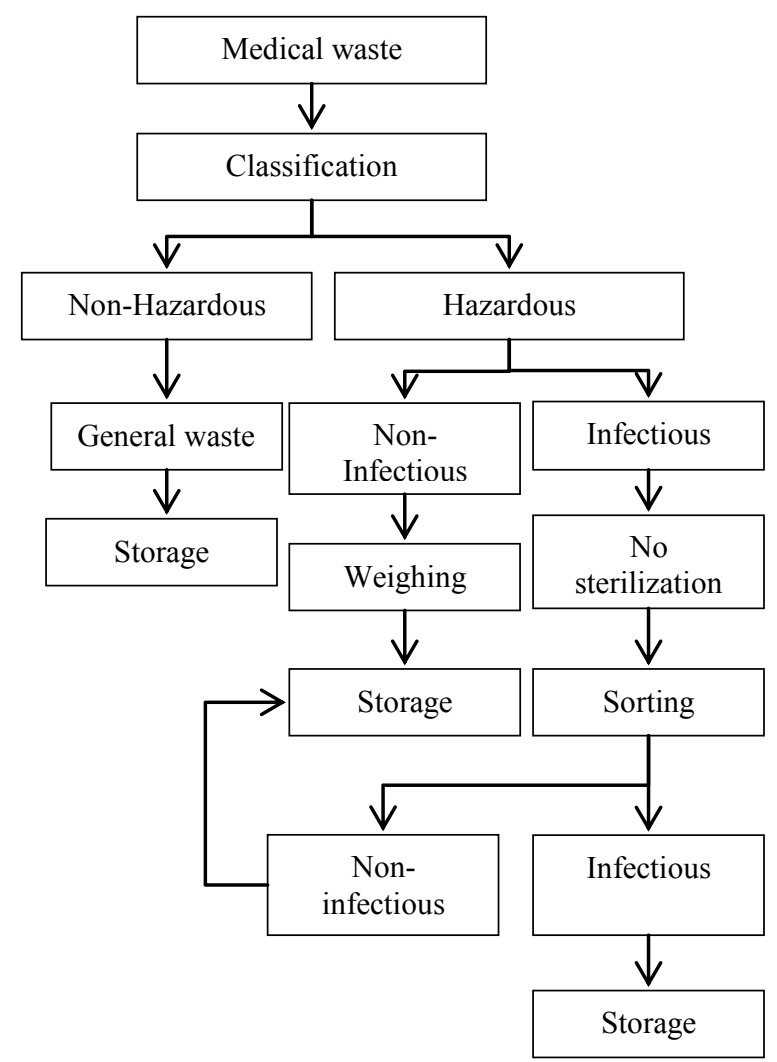

Fig.6. Treatment processes for infectious waste and non infectious waste at Hospital C 
As illustrated in Fig.6, hospital $\mathrm{C}$ the cleaning services worker sorted infectious waste in temporary storage. If the cleaning services worker found noninfectious and general waste in yellow plastic bag, they will took it from the yellow plastic bag and then collect it in black plastic bag. Procedurally, infectious waste that already collects in yellow plastic bag from treatment room cannot be open again, and keep it that way until arrived at infectious waste temporary storage. The impact of this infectious waste sorting practice will lead to general and non-infectious waste being automatically became infectious waste. At the end the general waste and non-infectious waste that already change the status became infectious waste will be transport from temporary storage to open dumping landfill area. Otherwise the cleaning services worker will risk exposure infectious diseases.

Temporary storage phase, condition of infectious temporary storage also varies between these three hospitals. At hospital A, the temporary storage between general wastes, non-infectious waste and infectious waste are in the same location. There is no door at temporary storage, this condition possible anyone and animal go inside to temporary storage. The temporary storage floor at hospital A is not in ceramic coated. This condition makes the cleaning services worker difficulty to clean the storage floor.

At hospital B and C, the temporary storage between general wastes, non-infectious waste and infectious waste are in different location. The conditions for temporary storage of infectious waste are in accordance with the regulations. They lock the temporary storage of infectious, only in charge worker who can enter the temporary storage. The temporary storage also already ceramic coated, this condition makes the worker easy to clean up the temporary storage. Infectious and non infectious located in different storage, this condition makes the lower risk that infectious waste will contaminated the non-infectious waste and general waste. At hospital A, B and C there is no cooler room facility, to storage infectious waste. The average temperature at temporary storage was $28-31^{\circ} \mathrm{C}$.

Disposal Phase, Hospital A, B and C have the same registered waste disposal companies who collect and transport the infectious waste. The disposal companies (outsourcing company) collect and transport at hospital $\mathrm{A}, \mathrm{B}$ and $\mathrm{C}$ twice a week. In this study show the infectious waste will stay more than 48 hours in temporary storage. Based on government regulation, if the infectious waste stay in temporary storage more than 48 hours, the infectious waste must located in the storage room with cooler facility to prevent the bacteria or other pathogen microorganism growth.

At hospital A, if the disposal companies who collect infectious waste from temporary storage being late from the schedule, the temporary storage will over capacity and the cleaning services worker will put the infectious container outside from temporary storage. The collection of infectious waste schedules are twice a week with a total of 14 container of infectious waste.
Standard regulation mention that the contents of the container should not exceed $2 / 3$ of the total volume of the, but in this study show that containers are overloaded, due this condition the outsourcing worker will step on the infectious waste before they put the container inside the infectious waste vehicle.

\subsection{Assessment of infectious waste management practices at Hospital A, B and C}

Evaluating the handling practices of infectious waste in Hospital is important to improve infectious waste management. Hospital with excellent accreditation level should conduct the infectious waste handling according to standard procedures. Comparison the result between the hospitals shows in Table 4.

Table.4. Assessment of Infectious waste management practices at Hospital A, B and C

\begin{tabular}{|l|c|c|c|c|c|c|}
\hline \multirow{2}{*}{ Parameter of Assessment } & \multicolumn{2}{|c|}{$\begin{array}{c}\text { Hospital } \\
\text { A }\end{array}$} & \multicolumn{2}{c|}{$\begin{array}{c}\text { Hospital } \\
\text { B }\end{array}$} & \multicolumn{2}{c|}{$\begin{array}{c}\text { Cospital } \\
\text { C }\end{array}$} \\
\cline { 2 - 7 } & NC & C & NC & C & NC & C \\
\hline Organizational Structure & & $\sqrt{ }$ & & $\sqrt{ }$ & & $\sqrt{ }$ \\
\hline $\begin{array}{l}\text { Status of Cleaning } \\
\text { services worker }\end{array}$ & & $\sqrt{ }$ & & $\sqrt{ }$ & & $\sqrt{ }$ \\
\hline $\begin{array}{l}\text { Classification/segregation } \\
\text { Phase }\end{array}$ & $\sqrt{ }$ & & & $\sqrt{ }$ & & $\sqrt{ }$ \\
\hline $\begin{array}{l}\text { Collect and transport } \\
\text { phase }\end{array}$ & $\sqrt{ }$ & & & $\sqrt{ }$ & $\sqrt{ }$ & \\
\hline Storage phase & $\sqrt{ }$ & & & $\sqrt{ }$ & & $\sqrt{ }$ \\
\hline Disposal phase & & $\sqrt{ }$ & & $\sqrt{ }$ & & $\sqrt{ }$ \\
\hline$\%$ Comply & & 50 & & 100 & & 83 \\
\hline
\end{tabular}

$\mathrm{NC}=$ Not comply according to standard procedures

$\mathrm{C}=$ Comply according to standard procedures

\section{Conclusions}

The infectious waste generated by hospital, which is heavily contaminated with pathogen microorganism, seldom receives the attention it deserves from researchers. Therefore, this study evaluated the practices of infectious waste at hospital with the highest accreditation level using observation and formal interview method. The infectious waste management practices assessment divided into six parameters: Organizational structure, status of cleaning services worker, classification/segregation, collect and transport phase, storage phase and disposal phase.

Failure of infectious waste treatment process in hospital is generally caused by human error. The status of outsourced cleaning services workers has a higher level of awareness and cautious of infectious waste danger compared to non-outsourcing cleaning service worker.

This study provides useful information for workers, decision-makers and public regarding the proper management of Infectious waste management and the sustainable development of waste management. From three hospital that have been observed, the hospital B achieved the highest score $(100 \%)$ for the infectious waste management procedures against six assessment parameters. Other side, hospital A and C scored 50\% and

\footnotetext{
Corresponding author: novie.fitria@gmail.com
} 
$83 \%$. This research proves that the level of excellent accreditation does not guarantee the implementation of infectious waste handling in accordance with the procedure. This study also increases the understanding of the potential problems associated with infectious waste, thereby increasing awareness of how to improve management of hospital infectious waste to better protect worker, public and environment.

The authors would like to thank to Department of health environment the hospital in Bandung, Cimahi and East Jakarta for the warm reception and valuable contribution given during the study. The works are financially supported by Minister of Research and Education of Indonesia and Department of Environmental engineering, Bandung Institute of Technology.

\section{References}

1. M. Oroei, M. Momeni, C.J. Palenik, M. Danaei, M. Askarian. Journal of infectious and Public Health, J. 7, pp 192-198, (2014)

2. A. Stankovic, D. Niki, M. Nikolic, Waste Management and Reasearh, 26, pp 309 - 313, (2008)

3. US Environmental Protection Agency (US EPA)., Medical waste. Available at : https://www.epa.gov/rcra/medical-waste (1992)

4. D. Komilis, A. Fouki, D. Papadopoulus, Waste Management, J. 32, pp 1434-1441, (2012)

5. N.C. Nwachukwu, F.A. Orji, O.C. Ugbogu, Epub.DOI : 10.5772/53196 (2013)
6. Peraturan pemerintah Indonesia (PP) 101/2014., Available at https://www.kemenkopmk.go.id/sites/default/files/pr odukhukum/PP\%20Nomor\%20101\%20Tahun\%2020 14_0.pdf (URL link)

7. World Health Organization (WHO)., Medical waste, Available at http://www.who.int/topics/medical_waste/en/, (URL link).

8. A. Bdour, B. Altrabsheh, N. Hadadin, M. Al-shareif, Waste Management, J. 27, pp 746-759, (2007)

9. N. Fitria, E. Damanhuri, 3rd Symposium of the Asian Regional Branch of International Waste Working Group, Departement of Civil and Environmental Engineering (ICEE), pp.59, (2017).

10. Ministry of health Indonesia (Permenkes 12/2012) Available at :

http://perpustakaan.bappenas.go.id/lontar/file?file=digita 1/122029-[Konten]Permenkes\%20No\%2012\%2020120001.pdf, (URL link)

11. M.A. Patwary, W.T. O’Hare, G. Street, K.M. Elahi, S.S. Hossain, M.H. Sarker, Waste Management, J. 29, pp 2392-2397, (2009)

12. R Kumari, K. Srivastava, A. Wakhlu, A. Singh, Clinical epidemiology and global health, J, 1, pp 131136, (2013)

13. Y.C. Chen, P.Y. Tsai, Waste Management \& Research, J. 35 pp 1-9, (2017)

* Corresponding author: novie.fitria@gmail.com 